\title{
Persepsi Siswa Terhadap Efektivitas Proses Belajar Mengajar Dan Hubungannya Dengan Hasil Belajar Matematik
}

\author{
May Fitriana Hasibuan \\ Dosen Program Studi Komputerisasi Akuntansi \\ Politeknik Trijaya Krama Medan, Jl. Iskandar Muda No. 1 Medan, Sumatera Utara 20154, \\ Indonesia \\ Email: may_fh27@ymail.com
}

\begin{abstract}
Abstrak-Matematika sebagai salah satu bagian dari pendidikan yang harus dipelajari oleh setiap peserta didik pada lembaga formal. Matematika juga salah satu bidang studi yang mempunyai peranan penting dan banyak kita jumpai dalam kehidupan sehari-hari. Sehingga tidak diragukan lagi bahwa matematika merupakan salah satu puncak kegemilangan intelektual. Secara etimologi persepsi itu berasal dari bahasa inggris yaitu "perception" yang artinya tanggapan, daya memahami sesuatu. Persepsi dapat juga diartikan sebagai proses diterimanya rangsangan dimana rangsangan itu berupa objek, kualitas, hubungan antara gejala, maupun peristiwa, sampai rangsangan itu disadari dan dimengerti. Tujuan penelitian ini diantaranya memperoleh data yang objektif tentang persepsi siswa pada proses belajar mengajar matematika. Memperoleh data yang objektif tentang hasil belajar siswa serta mengetahui sejauh mana keterkaiatan persepsi siswa terhadap efektifitas proses belajar mengajar matematika dari siswa kelas VIII SMP Nur Ilmi Percut Sei Tuan. Dari hasil penelitian ini diperoleh perhitungan hasil rata-rata $X_{1}=60.63$ dan disimpangan baku $\mathrm{S}_{1}=7.09$ diambil dari angka yang dibagikan pada siswa, dan rata-rata $X_{2}=72.44$ dan simpangan baku $\mathrm{S}_{2}=3.88$ diambil dari rata-rata hasil belajar siswa. Statistika yang digunakan adalah uji t signifikan dengan taraf signifikan $a=0.05$ dan derajat kథebasan $=76$. Perhitungan memberikan thitung $=11.8$. Dengan menggunakan table distribusi tstudent pada taraf signifikan $a=0.05$ dan derajat kebebasan $=76$ diperoleh $=2.04$. hasil ini menunjukkan bahwa thitung $>$ tabel. Dengan demikian $\mathrm{H}_{\mathrm{o}}$ ditolak dan dengan kata lain $\mathrm{H}_{\mathrm{a}}$ diterima. Kesimpulan yang diperoleh dari analisis data menunjukkan bahwa ada hubungan yang berarti antar persepsi dan efektivitas siswa pada proses belajar mengajar pelajaran matematika terhadap hasil belajar matematika siswa.
\end{abstract}

Kata kunci : Persepsi, Efektivitas, Proses Belajar, Hasil Belajar Matematika,

\begin{abstract}
Mathematics as one part of education that must be learned by each student in formal institutions. Mathematics is also one of the fields of study that has an important role and many of us meet in everyday life. So there is no doubt that mathematics is one of the pinnacles of intellectual glory. Etymologically the perception comes from English, namely "perception" which means response, the power to understand something. Perception can also be interpreted as the process of receiving stimuli where stimuli are in the form of objects, qualities, relationships between symptoms, and events, until the stimulus is realized and understood. The purpose of this study includes obtaining objective data about student perceptions in the learning process of mathematics. Obtain objective data about student learning outcomes and find out the extent to which students' perceptions of the effectiveness of the mathematics teaching and learning process of class VIII SMP Nur Ilmi Percut Sei Tuan. From the results of this study the calculation of the results of the average $\mathrm{X} \otimes=60.63$ and the standard deviation $\mathrm{S} 1=7.09$ is taken from the numbers shared with students, and the average $X \mathbb{Q}=72.44$ and standard deviation $\mathrm{S} 2=3.88$ taken from the average student learning outcomes. The statistics used are significant $t$ test with a significant level of $a=0.05$ and degrees of freedom $=76$. Calculations providectunt $=11.8$. By using the tstudent distribution table at a significant level of $a=0.05$ and the degree of freedom $=76$ obtained $=$ 2.04. this result shows that tcount $>$ table. Thus Ho is rejected and in other words Ha is accepted. The conclusions obtained from data analysis showed that there was a meaningful relationship between the perceptions and effectiveness of students in the learning process of mathematics lessons on students' mathematics learning outcomes.
\end{abstract}

Keywords: Perception, Effectiveness, Learning Process, Mathematics Learning Outcomes,

\section{Pendahuluan}

Matematika merupakan salah satu bagian dari pendidikan yang harus dipelajari oleh setiap peserta didik pada lembaga formal. Metode matematis memberikan inspirasi kepada pemikiran di bidang sosial dan ekonomi. Disamping itu pemikiran matematis memberikan warna kepada kegiatan-kegiatan seni lukis, arsitektur dan 
musik. Akhirnya matematika merupakan salah satu kekuatan utama pembentuk konsep tentang alam serta hakikat dan tujuan manusia dalam kehidupan. Hudojo (1998) mengungkapkan bahwa: "Matematika bukanlah ilmu yang banyak untuk keperluan dirinya sendiri, tetapi ilmu yang bermanfaat untuk sebagaian besar ilmu-ilmu lain". Guru telah menyelesaikan soal-soal yang diujikan dengan materi pelajaran yang disajikan dalam proses belajar mengajar. Dengan adanya kesempatan ujian dengan materi pembelajaran, diharapkan siswa mampu memberikan jawaban yang benar. Tetapi kenyataan setelah ujian, hasil ujian tidak seperti yang diharapkan oleh guru. Hal seperti inilah yang menunjukkan adanya suatu masalah yang dihadapi siswa dalam belajar sehingga prestasi belajar rendah. Padahal mereka memperoleh dan mempelajari dengan materi yang sama dan guru yang sama pula. Ini menunjukkan adanya perbedaan kemampuan daya pikir siswa dan hal lain yang mengakibatkan semuanya terjadi diantaranya faktor lingkungan, ekonomi dan faktor kejiwaan serta kondisi fisik dari siswa. Secara umum perbedaan kemampuan dan factor kejiwaan adalah hal yang mempengaruhi hasil belajar siswa. Dimana factor kejiwaan yang dimaksud adalah minat, motivasi, persepsi dan lain-lain yang berhubungan dengan jiwa seseorang. Factor kejiwaan mengenai persepsi terhadap proses belajar dan materi pelajaran matematika dari siswa-siswa mungkin saja berbeda. Ada yang persepsinya baik dan adapula yang berpendapat bahwa guru dalam pelajaran matematika itu menakutkan. Persepsi seperti inilah yang menyebabkan siswa tidak tertarik dan tidak termotivasi untuk mempelajari matematika secara sungguh-sungguh.

\section{Kajian Pustaka}

\subsection{Pengertian Persepsi}

Secara etimologi persepsi itu berasal dari bahasa inggris yaitu "perception" yang artinya tanggapan, daya memahami sesuatu. Oleh morgan dalam Rukminto (1991) menyatakan bahwa : Persepsi menunjukkan kepada bagaimana kita melihat, mendengar, merasakan dan mencium dunia disekitar kitĐYengan demikian persepsi berkaitan dengan pikiran, perasaan, fantasi, dan segenap unsur jiwa lainnya.

Berikut ini beberapa prinsip dasar tentang persepsi yang perlu diketahui oleh seorang guru:

a. Persepsi itu relative bukan absolut.

b. Persepsi itu selektif.

c. Persepsi itu mempunyai tatanan.

d. Persepsi dipengaruhi oleh harapan dan kesiapan (penerima rangsangan)

e. Persepsi seseorang atau kelompok dapat juga berbeda walaupun situasinya sama.

2.2 Pengertian Efektivitas Belajar

Mengajar yang efektif menurut Slameto (2003:92) ialah: "Mengajar yang dapat membawa belajar siswa yang efektif pula yaitu belajar atau suatu aktivitas mencari, menemukan dan melihat pokok masalah". Untuk melaksanakan mengajar yang efektif diperlukan syarat-syarat sebagai berikut:

a. Belajar secara aktif.

b. Guru harus mempergunakan banyak metode pada waktu mengajar.

c. Motivasi

d. Kurikulum yang baik dan seimbang.

e. Guru harus memperhatikan perbedaan karakter siswa.

f. Adanya perencanaan sebelum mengajar.

g. Memiliki sugesti sebagai guru.

h. Menciptakan suasana sekolah yang demokrasi.

i. Mampu merangsang berpikir siswa.

j. Guru mampu menghadapi keberanian siswa.

k. Pelajaran yang diberikan harus diintegrasikan.

1. Pelajaran yang disampaikan harus dihubungkan dengan realisasi.

$\mathrm{m}$. Guru harus memberikan kebebasan pada siswa dalam berpikir.

n. Memberikan pengajaran remedial

\subsection{Pengertian Proses Belajar}

Proses adalah kata yang berasal dari bahasa latin "procesus" yang berarti "berjalan ke depan". Kata ini mempunyai konotasi urutan langkah atau kemajuan yang mengarah pada suatu sasaran atau tujuan. Sedangkan belajar merupakan kegiatan setiap orang. Pendapat purwanto (1991:15) menyatakan bahwa: "Belajar adalah suatu perubahan dalam tingkah laku yang lebih baik, tetapi juga kemungkinan mengarah kepada tingkah laku yang yang lebih buruk". Jadi dapat disimpulkan bahwa aktivitas belajar disekolah itu pada intinya adalah untuk melakukan perubahan pada diri anak didik. Ini berarti bahwa seseorang yang telah mengalami proses belajar itu akan mengalami perubahan tingkah laku, baik aspek pengetahuan, keterampilan, maupun sikapnya.

\subsection{Pengertian Mengajar}


Tardif (1987) mendefenisikan mengajar siswa lebih sederhana dengan menyatakan bahwa mengajar adalah "perbuatan yang dilakukan seseorang (dalam hal ini guru dengan tujuarembantu atau memudahkan orang lain (dalam hal ini siswa) melakukan kegiatan belajar".

Biggs (1991), seorang pakar psikologi kognitif masa kini, membagi tiga macam konsep mengajar:

1. Kuantitatif (jumlah pengetahuan yang diajarkan)

2. Institutsional (kelembagaan atau sekolah)

3. Kualitatif (mutu hasil yang ideal)

\subsection{Pengertian Hasil Belajar}

Kegiatan dari usaha untuk mencapai perubahan tingkah laku merupakan proses belajar. Sedangkan perubahan tingkah laku itu sendiri merupakan hasil belajar. Hal ini sesuai dengan Nasution (1982:24) menegaskan bahwa: "Hasil belajar adalah suatu perubahan yang terjadi padadividu yang belajar bukan saja perubahan untuk membentuk kecakapan, kebiasaan, sikap, pengertian, dan penguasaan dalam diri individu yang belajar".

Jadi untuk mendapatkan hasil yang baik dan memuaskan tergantung pada diri siswa itu sendiri. Jika menginginkan hasil belajar yang baik dan memuaskan siswa harus belajar dan dibarengi dengan skap ketekunan, ketabahan dan keuletan serta kainginan untuk belajar.

\section{METODE PENELITIAN}

\subsection{Teknik Analisis Data}

a. Mencari rata-rata dan simpangan baku

Rumus:

$x_{1}=\frac{f x}{f_{i}} \operatorname{dan} S=\frac{f x-f x^{2}}{n n-1}$

\section{b. Uji Normalitas}

1. Pengamatan $X_{1}, X_{2}, X_{3}, \ldots, X_{n}$ dijadikan bilangan baku $Z_{1}, Z_{2}, Z_{3}, \ldots, Z_{n}$ dengan rumus: $Z_{1} \bigotimes \frac{X, \bigotimes \bar{X}}{S}$ Dimana:

$\bar{X}=$ rata-rata

$\mathrm{S}$ = simpangan baku sampel

2. Untuk tiap bilanga baku ini dengan menggunakan daftar distribusi normal baku kemudian dihitung peluang $F\left(Z_{I}\right) \bigotimes P\left(Z \bigotimes Z_{i}\right)$.

3. Selanjutnya dihitung proporsi $Z_{1}, Z_{2}, Z_{3}, \ldots, Z_{n}$ yang lebih kecil atau sama dengan $Z_{i}$, jika proporsi ini dinyatakan dengan $S\left(Z_{i}\right) \otimes \frac{\text { banyaknya } Z_{1}, Z_{2}, Z_{3}, \ldots, Z_{n} \text { yang } \otimes Z_{i}}{n}$

4. Menghitung selisih $F\left(Z_{i}\right)-S\left(Z_{i}\right)$ kemudian menentukan harga mutlaknya.

5. Ambil harga mutlak yang terbesar disebut $\left(L_{0}\right)$. Untuk menerima atau menolak hipotesis, kita bandingkan $L_{0}$ dengan nilai kritis L yang diambil dari daftar, untuk taraf nyata $\triangle \otimes 0,005$. Dengan kriteria:

Jika $L_{0}<L_{\text {tabel }}$ maka sampel berdistributif normal.

Jika $L_{0}>L_{\text {tabel }}$ maka sampel tidak berdistributif normal.

c. Uji Hipotesis

Untuk mengetahui apakah variable $\mathrm{x}$ dan y mempunyai hubungan yang berarti, maka perlu dilakukan pengujian terhadap hipotesisi mengenai populasi dengan menggunakan hipotesis:

$\mathrm{HO}: \mathrm{b}_{1}=0$ : Tidak terdapat hubungan yang signifikan antara persepsi siswa terhadap efektivitas proses belajar mengajar pelajaran matematika dengan hasil belajar matematika.

$\mathrm{HO}: \mathrm{b}_{1} \neq 0$ : Terdapat hubungan yang signifikan antara persepsi siswa terhadap efektivitas proses belajar mengajar pelajaran matematika dengan hasil belajar matematika.

$t=\frac{r \overline{n-2}}{\overline{1-r^{2}}}$

Untuk pengujian hipotesis nol, $\mathrm{HO}: \rho=0$ digunakan uji statistik tlengan rumus Sudjana (1992):

Dengan menggunakan $\mathrm{dk}=\mathrm{n} 2-2$ maka $\mathrm{a}=0.05$, maka hipotesis diterima jika $t<t_{(1-0,5 \alpha)}$ atau $\mathrm{H} 0$ ditolak jika $t \geq t_{\text {tabel }}$. 


\section{Hasil Penelitian Dan Pembahasan}

\subsection{Hasil Penelitian}

Data yang dikumpulkan dalam penelitian ini terdiri dari 2 macam yaitu persepsi siswa terhadap efektivitas siswa pada proses belajar mengajar dan data hasil belajar siswa kelas VIII SMP Nur Ilmu Percut Sei Tuan.

Untuk memudahkan perhitungan dibuat dalam bentuk tabel dengan $X$ sebagai persepsi siswa terhadap efektivitas proses belajar mengajar dan Y sebagai hasil belajar matematika yang diambil dari nilai semester matematika siswa.

Tabel I

Persepsi Siswa Terhadap Efektivitas Proses Belajar Mengajar Dan Hubungannya Dengan Hasil Belajar Matematika Siswa

\begin{tabular}{|c|c|c|c|c|c|}
\hline $\begin{array}{c}\mathrm{N} \\
\mathrm{o} .\end{array}$ & $x_{i}$ & $y_{i}$ & $x_{1^{2}}$ & $y_{1^{2}}$ & $x_{i} y_{i}$ \\
\hline 1 & 55 & 70 & 3025 & 4900 & 3850 \\
\hline 2 & 62 & 72 & 3844 & 5184 & 4464 \\
\hline 3 & 59 & 71 & 3481 & 5041 & 4189 \\
\hline 4 & 66 & 73 & 4356 & 5329 & 4818 \\
\hline 5 & 70 & 75 & 4900 & 5625 & 5250 \\
\hline 6 & 60 & 73 & 3600 & 5329 & 4380 \\
\hline 7 & 52 & 70 & 2704 & 4900 & 3640 \\
\hline 8 & 63 & 71 & 3969 & 5041 & 4473 \\
\hline 9 & 68 & 73 & 4624 & 5329 & 4964 \\
\hline 10 & 60 & 75 & 3600 & 5625 & 4500 \\
\hline 11 & 71 & 78 & 5041 & 6084 & 5538 \\
\hline 12 & 48 & 60 & 2304 & 3600 & 2880 \\
\hline 13 & 70 & 77 & 4900 & 5929 & 5390 \\
\hline 14 & 70 & 76 & 4900 & 5776 & 5320 \\
\hline 15 & 60 & 75 & 3600 & 5625 & 4500 \\
\hline 16 & 65 & 76 & 4225 & 5776 & 4940 \\
\hline 17 & 56 & 76 & 3136 & 5776 & 4256 \\
\hline 18 & 57 & 70 & 3249 & 4900 & 3990 \\
\hline 19 & 57 & 71 & 3249 & 5041 & 4047 \\
\hline 20 & 64 & 74 & 4096 & 5476 & 4736 \\
\hline 21 & 64 & 75 & 4096 & 5625 & 4800 \\
\hline 22 & 62 & 73 & 3844 & 5329 & 4526 \\
\hline 23 & 62 & 72 & 3844 & 5184 & 4464 \\
\hline 24 & 61 & 70 & 3721 & 4900 & 4270 \\
\hline 25 & 73 & 82 & 5329 & 6724 & 5986 \\
\hline 26 & 43 & 66 & 1849 & 4356 & 2838 \\
\hline 27 & 63 & 72 & 3969 & 5184 & 4536 \\
\hline 28 & 56 & 70 & 3136 & 4900 & 3920 \\
\hline 29 & 56 & 70 & 3136 & 4900 & 3920 \\
\hline 30 & 56 & 72 & 3136 & 5184 & 4032 \\
\hline 31 & 67 & 73 & 4489 & 5329 & 4891 \\
\hline 32 & 68 & 77 & 4624 & 5929 & 5236 \\
\hline 33 & 68 & 77 & 4624 & 5929 & 5236 \\
\hline 34 & 61 & 74 & 3721 & 5476 & 4514 \\
\hline 35 & 49 & 69 & 2401 & 4761 & 3381 \\
\hline 36 & 49 & 68 & 2401 & 4624 & 3332 \\
\hline 37 & 51 & 69 & 2601 & 4761 & 3519 \\
\hline 38 & 62 & 68 & 3844 & 4624 & 4216 \\
\hline$\Sigma$ & 2304 & 2753 & 141568 & 200005 & 167742 \\
\hline
\end{tabular}

$x=\frac{x_{i}}{n}$

$=\frac{3204}{38}$ 


$$
\begin{aligned}
& =60.63 \\
& y=\frac{y_{i}}{n} \\
& =\frac{2753}{38} \\
& =72.44
\end{aligned}
$$

Berdasarkan hasil perhitungan yang diperoleh dari 38 siswa diketahui nilai rata-rata untuk persepsi siswa adalah $X=60.63$ dan simpangan bakunya $\mathrm{S}_{1}=7.09$. sedangkan untuk hasil belajar siswa adalah $X=72.44$ dan simpangan bakunya adalah $\mathrm{S}_{1}=3.88$.

\section{a. Rata-rata Simpangan Baku}

Untuk menghitung mean dan simpangan baku pada persepsi dan efektivitas siswa pada proses belajar mengajar pelajaran matematika dapat dilihat dari tabel berikut:

\section{Tabel 2.}

Perhitungan rata-rata dan simpangan baku pada persepsi dan efektivitas siswa pada proses belajar mengajar pelajaran matematika

\begin{tabular}{|c|c|c|c|c|}
\hline$x_{1}$ & $f_{1}$ & $f_{1} x_{1}$ & $x_{1^{2}}$ & $f_{1} x_{1^{2}}$ \\
\hline 43 & 1 & 43 & 1849 & 1849 \\
\hline 48 & 1 & 48 & 2304 & 2304 \\
\hline 49 & 2 & 98 & 2401 & 4802 \\
\hline 51 & 1 & 51 & 2601 & 2601 \\
\hline 52 & 1 & 52 & 2704 & 2704 \\
\hline 55 & 1 & 55 & 3025 & 3025 \\
\hline 56 & 3 & 168 & 3136 & 9408 \\
\hline 57 & 2 & 114 & 3249 & 6498 \\
\hline 58 & 1 & 58 & 3364 & 3364 \\
\hline 59 & 1 & 59 & 3481 & 3481 \\
\hline 60 & 3 & 180 & 3600 & 10800 \\
\hline 61 & 2 & 122 & 3721 & 7442 \\
\hline 62 & 4 & 248 & 3844 & 15376 \\
\hline 63 & 2 & 126 & 3969 & 7938 \\
\hline 64 & 2 & 128 & 4096 & 8192 \\
\hline 65 & 1 & 65 & 4225 & 4225 \\
\hline 66 & 1 & 66 & 4356 & 4356 \\
\hline 67 & 1 & 67 & 4489 & 4489 \\
\hline 68 & 3 & 204 & 4624 & 13872 \\
\hline 70 & 3 & 210 & 4900 & 14700 \\
\hline 71 & 1 & 71 & 5041 & 5041 \\
\hline 73 & 1 & 73 & 5329 & 5329 \\
\hline$\Sigma$ & 38 & 2306 & 80308 & 141796 \\
\hline & & &
\end{tabular}

$$
\begin{aligned}
x_{1} & =\frac{f_{i} x_{i}}{f_{i}} \\
& =\frac{2360}{38} \\
& =60.68
\end{aligned}
$$

$S_{1}^{2}=\frac{n \quad f_{1} x_{1}^{2}-f_{1} x_{1}^{2}}{n n-1}$ 


$$
\begin{aligned}
& =\frac{38141796-2306^{2}}{3838-1} \\
& =\frac{5388248-5317636}{1406} \\
& =\frac{70612}{1406} \\
S_{1}^{2} & =50.22 \\
S_{1} & =\overline{50.22} \\
S_{1} & =7.09
\end{aligned}
$$

Tabel 3

Perhitungan Rata-Rata Dan Simpangan Baku Pada Hasil Belajar Matematika Siswa

\begin{tabular}{|c|c|c|c|c|}
\hline$x_{1}$ & $f_{1}$ & $f_{1} x_{1}$ & $x_{1}{ }^{2}$ & $f_{1} x_{1}{ }^{2}$ \\
\hline 60 & 1 & 60 & 3600 & 3600 \\
\hline 66 & 1 & 66 & 4356 & 4356 \\
\hline 68 & 2 & 136 & 4624 & 9248 \\
\hline 69 & 2 & 138 & 4761 & 9522 \\
\hline 70 & 6 & 420 & 4900 & 29400 \\
\hline 71 & 3 & 213 & 5041 & 15123 \\
\hline 72 & 4 & 288 & 5184 & 20736 \\
\hline 73 & 5 & 365 & 5329 & 26645 \\
\hline 74 & 2 & 148 & 5476 & 10952 \\
\hline 75 & 4 & 300 & 5625 & 22500 \\
\hline 76 & 3 & 228 & 5776 & 17328 \\
\hline 77 & 3 & 231 & 5929 & 17787 \\
\hline 78 & 1 & 78 & 6084 & 6084 \\
\hline 82 & 1 & 82 & 6724 & 6724 \\
\hline$\Sigma$ & 38 & 2753 & 73409 & 200005 \\
\hline
\end{tabular}

$$
\begin{aligned}
x_{1} & =\frac{f_{i} x_{i}}{f_{i}} \\
& =\frac{2753}{38} \\
& =72.45
\end{aligned}
$$

$$
\begin{aligned}
S_{2}^{2} & =\frac{n f_{1} x_{1}^{2}-f_{1} x_{1}{ }^{2}}{n n-1} \\
& =\frac{38200005-2753^{2}}{3838-1} \\
& =\frac{7600190-757009}{1406} \\
& =\frac{21181}{1406} \\
S_{2}^{2} & =15.06 \\
S_{2} & =\frac{50.22}{S_{2}} \\
= & 3.88
\end{aligned}
$$




\section{b. Uji Normalitas Data}

Tabel 3.

Uji normalitas data persepsi dan efektivitas siswa pada proses belajar mengajar pada pelajaran matematika

\begin{tabular}{|c|c|c|c|c|c|c|}
\hline $\begin{array}{c}\text { Nil } \\
\text { ai }\end{array}$ & $F_{1}$ & $F_{k}$ & $Z_{1}$ & $F\left(Z_{1}\right)$ & $S\left(Z_{1}\right)$ & $\begin{array}{c}F\left(Z_{1}\right) \\
-S\left(Z_{1}\right)\end{array}$ \\
\hline 43 & 1 & 1 & -2.49 & 0.0064 & 0.26 & 0.0199 \\
\hline 48 & 1 & 2 & -1.77 & 0.0374 & 0.05 & 0.0126 \\
\hline 49 & 2 & 4 & -1.63 & 0.0516 & 0.105 & 0.053 \\
\hline 51 & 1 & 5 & -1.35 & 0.0881 & 0.1316 & 0.043 \\
\hline 52 & 1 & 6 & -1.22 & 0.1112 & 0.1579 & 0.0467 \\
\hline 55 & 1 & 7 & -0.80 & 0.2119 & 0.1842 & 0.0277 \\
\hline 56 & 3 & 10 & -0.66 & 0.2546 & 0.2632 & 0.0086 \\
\hline 57 & 2 & 12 & -0.51 & 0.3016 & 0.3156 & 0.0141 \\
\hline 58 & 1 & 13 & -0.37 & 0.3520 & 0.3421 & 0.0099 \\
\hline 59 & 1 & 14 & -0.23 & 0.4052 & 0.3684 & 0.0368 \\
\hline 60 & 3 & 17 & -0.09 & 0.4641 & 0.4474 & 0.0167 \\
\hline 61 & 2 & 19 & 0.04 & 0.5199 & 0.5000 & 0.0199 \\
\hline 62 & 4 & 23 & 0.18 & 0.5754 & 0.6053 & 0.0299 \\
\hline 63 & 2 & 25 & 0.32 & 0.6293 & 0.6579 & 0.0286 \\
\hline 64 & 2 & 27 & 0.46 & 0.6808 & 0.7105 & 0.0297 \\
\hline 65 & 1 & 28 & 0.60 & 0.7291 & 0.7368 & 0.0077 \\
\hline 66 & 1 & 29 & 0.75 & 0.7734 & 0.7672 & 0.0062 \\
\hline 67 & 1 & 30 & 0.89 & 0.8133 & 0.7895 & 0.0238 \\
\hline 68 & 3 & 33 & 1.03 & 0.8485 & 0.8684 & 0.0199 \\
\hline 70 & 3 & 36 & 1.31 & 0.9019 & 0.9474 & 0.0455 \\
\hline 71 & 1 & 37 & 1.45 & 0.9279 & 0.9737 & 0.0542 \\
\hline 73 & 1 & 38 & 1.73 & 0.9591 & 1.0000 & 0.0173 \\
\hline
\end{tabular}

Dari tabel diatas di dapat $\mathrm{L}_{0}=0.0542$ dengan $\mathrm{n}=38$ dan taraf nyata $\mathrm{a}=0.05$ dari daftar nilai kritis Liliefors di dapat $\mathrm{L}_{\mathrm{t}}=0.143$. Oleh karena harga $\mathrm{L}_{\mathrm{O}}<\mathrm{L}_{\mathrm{t}}$ maka dapat disimpulkan bahwa sampel berdistribusi normal.

Tabel 5.

Uji normalitas data pada hasil belajar matematika siswa

\begin{tabular}{|c|c|c|c|c|c|c|}
\hline Nilai & $F_{1}$ & $F_{k}$ & $Z_{1}$ & $F\left(Z_{1}\right)$ & $S\left(Z_{1}\right)$ & $F\left(Z_{1}\right)-S\left(Z_{1}\right)$ \\
\hline 60 & 1 & 1 & -3.26 & 0.0006 & 0.026 & 0.0254 \\
\hline 66 & 1 & 2 & -1.68 & 0.0465 & 0.0521 & 0.0055 \\
\hline 68 & 2 & 4 & -1.15 & 0.1251 & 0.1051 & 0.02 \\
\hline 69 & 2 & 6 & -0.89 & 0.1812 & 0.157 & 0.0242 \\
\hline 70 & 6 & 12 & -0.63 & 0.1643 & 0.3158 & 0.0515 \\
\hline 71 & 3 & 15 & -0.37 & 0.3557 & 0.3947 & 0.0390 \\
\hline 72 & 4 & 19 & -0.11 & 0.4522 & 0.5000 & 0.0478 \\
\hline 73 & 5 & 24 & 0.14 & 0.5557 & 0.9632 & 0.0759 \\
\hline 74 & 2 & 26 & 0.39 & 0.6554 & 0.6892 & 0.0288 \\
\hline 75 & 4 & 30 & 0.65 & 0.7454 & 0.7895 & 0.0441 \\
\hline 76 & 3 & 33 & 0.91 & 0.8186 & 0.8684 & 0.498 \\
\hline 77 & 3 & 36 & 1.17 & 0.8790 & 0.9474 & 0.0684 \\
\hline 78 & 1 & 37 & 1.43 & 0.9236 & 0.9737 & 0.0501 \\
\hline 82 & 1 & 38 & 2.46 & 0.9931 & 1.0000 & 0.0069 \\
\hline
\end{tabular}

Dari tabel diatas di dapat $\mathrm{L}_{\mathrm{O}}=0.0759$ dengan $\mathrm{n}=38$ dan taraf nyata $\mathrm{a}=0.05$ dari daftar nilai kritiLiliefors di dapat $\mathrm{L}_{\mathrm{t}}=0.143$. Oleh karena harga $\mathrm{L}_{\mathrm{O}}<\mathrm{L}_{\mathrm{t}}$ maka dapat disimpulkan bahwa sampel berdistribusi normal.

\section{c. Uji Hipotesis}

1. Korelasi product moment

Menentukan korelasi product moment untuk mengetahui seberapa besar hubungan antara variable $\mathrm{X}$ dan $\mathrm{Y}$ digunakan rumus korelasi product moment yaitu:

$r_{x y}=\frac{N \quad X Y-X \quad Y}{} \frac{N X^{2}-X^{2} N Y^{2}-Y^{2}}{N}$ 


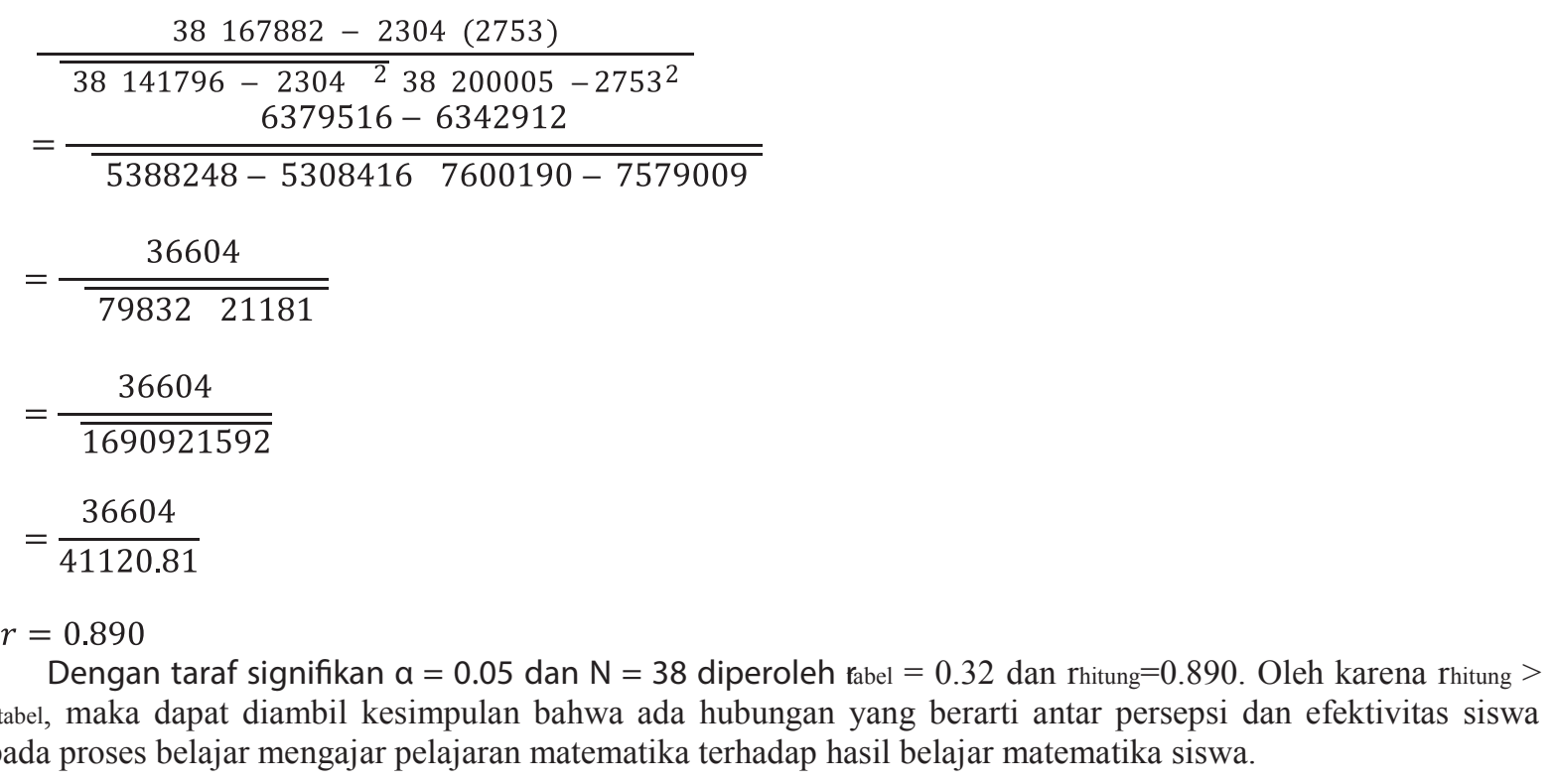

2. Uji t Signifikan

Untuk melihat keberartian atau signifikansinya, kedua hubungan digunakan rumus uji t signifikan yaitu:

$$
\begin{aligned}
t & =\frac{r \overline{n-2}}{\overline{1-r^{2}}} \\
& =\frac{0.890 \overline{38-2}}{\overline{1-0.890^{2}}} \\
& =\frac{5.34}{0.456} \\
& =11.8
\end{aligned}
$$

Dari tabel diperoleh t dengan $a=5 \%$ adalah 2.04 sedangkanitung $=1.18$ maka thitung $>$ ttabel. Dengan demikian korelasi kedua variable berarti. Sedangkan untuk mencari berapa besar kontribusi antara variable digunakan rumus uji determinasi dengan rumus:

$$
\begin{aligned}
r^{2} & =\frac{b n X_{1} Y_{1}-X_{1} Y_{1}}{n Y_{1}^{2}-Y_{1}^{2}} \\
& =\frac{0.4538167882-2304(2753)}{38200005-(2753)^{2}} \\
& =\frac{0.456379516-6342912}{7600190-7579009} \\
& =\frac{0.4536604}{21181} \\
& =\frac{16471.8}{21181} \\
& =0,777
\end{aligned}
$$

Dengan menggunakan rumus determinasi:

$$
\begin{aligned}
D & =r^{2} \times 100 \% \\
& =0.777 \times 100 \% \\
& =77.7 \%
\end{aligned}
$$


Jadi besarnya kontribusi variable X terhadap Y sebesar $77.7 \%$ dan sisanya $22.3 \%$ dipengaruhi oleh factor-faktor lainnya.

\subsection{Pembahasan}

Dari hasil penelitian secara umum persepsi dan efektivitas siswa pada proses belajar mengajar pelajaran matematika Tahun Pembelajaran 2017/2018 termasuk dalam kategori tinggi sebanyak 21 orang (55.26\%) sedangkan kategori cukup sebanyak 17 orang (44.74\%) sedangkan kategori kurang dan rendah tidak diperoleh. Untuk hasil belajar matematika siswa termasuk dalam kategori cukup sebanyak 26 orang (68.42\%) sedangkan kategori tinggi sebanyak 12 orang (31.58\%) sedangkan kategori kuran dan rendah tidak diperoleh. Dari pengujian korelasi ditemukan bahwa korelasi antara ubahan persepsi dan efektivitas pada proses belajar mengajar pelajaran matematika terhadap hasil belajar matematika siswa adalah positif.

\section{Kesimpulan}

1. Adanya hubungan yang signifikan antara persepsi siswa tentang efektivitas proses belajar mengajar dan ada hubungannya dengan hasil belajar matematika siswa kelas VII SMP Nur Ilmi Percut Sei Tuan Tahun Pelajaran 2017/2018 koefisien korelasi 0.890 dengan taraf nyata $€ 0.05$. Bila dibandingkan dengan Ttabel 0.320 maka rhitung $>$ rtabel yaitu $0.890>0.320$.

2. Melalui hasil pengujian hipotesis diperoleh $11.8>2.04$ sehingga dapat disimpulkan bahwa hipotesis diterima yaitu adanya hubungan yang signifikan antara persepsi siswa dan efektivitas proses belajar mengajar dan hubungannya dengan hasil belajar matematika siswa kelas VII SMP Nur Ilmi Percut Sei Tuan Tahun Pelajaran 2017/2018.

3. Besar kontribusi persepsi siswa dan efektivitas proses belajar mengajar dan hubungannya dengan hasil belajar matematika siswa kelas VII SMP Nur Ilmi Percut Sei Tuan Tahun Pelajaran 2017/2018 adalah $77.7 \%$ yang artinya keterkaiatan persepsi belajar siswa dengan hasil belajar mencapai angka 77.7\%. Dan selebihnya (23.3\%) dipengaruhi faktor-faktor lain.

\section{Referensi}

[1] Aritin, H.M. (1978). Hubungan Timbal Balik Pendidikan Agama di Lingkungan Sekolah dan Keluarga. Jakarta, Bulan Bintang.

[2] Biggs, John, B (1991), The of Matelearning Study Process. Penerjemah Muhibbin Syah. Bandung, Remaja Rosdakarya.

[3] Hudojo, Herman (1998). Belajar Mengajar Matematika. Jakarta, : Dep P dan K.

[4] Nasution, S. (1982). Berbagai Pendekatan Dalam Proses Belajar Mengajar. Jakarta: Bina Aksara.

[5] Rukminto, Isbandi (1991). Psikologi Pekerjaan Sosial dan Ilmu Kesejahteraan Sosial. Jakarta : Rineka Cipta.

[6] Slameto (1995). Belajar dan Faktor-faktor Yang Mempengaruhinya. Jakarta : Rineka Cipta.

[7] Sudjana. (1992). Metode Statistik. Bandung: Tarsito.

[8] Tardif, Richard (1987). The Penguin Macquarie Dictioanry of Australian Education. Penerjemah Muhibbin Syah. Bandung, Remaja Rosdakarya. 